\title{
Insight \\ Mechanisms to Improve Integrative Research at the Science-Policy Interface for Sustainable Catchment Management
}

\author{
Christopher (Kit) J. A. Macleod ${ }^{1}$, Kirsty L. Blackstock, and Phil M. Haygarth
}

\begin{abstract}
Greater integration between researchers and policy makers is required to provide an evidence base that is transparent, integrated, and adaptive to support the complexities of sustainable catchment management. Opening-up and closing-down mechanisms are equally important in creating and establishing such an evidence base. We provide examples of both types based on our recent research and knowledgetransfer activities at the science-policy interface. Through our coordination role for the United Kingdom government we provide opening up physical and virtual forums for researchers and government science and policy staff to learn about and assess the gaps and uncertainties of the evidence base. Closing-down mechanisms are vital to policy cycles, in that they distil what is known and what is unknown. The Diffuse Pollution User Manual provides a valuable tool for policy and catchment management staff to assess the potential effectiveness of different combinations of remedial diffuse-pollution mitigation methods. It is vital that that opening-up and closing-down mechanisms are iteratively linked given the complexity and uncertainty of the science and policy cycles. Advances in integrative research at the science-policy interface are vital if there is to be a move to more deliberative policy making.
\end{abstract}

Key Words: catchment; diffuse pollution; evidence base; integrative; science-policy; UK.

\section{INTRODUCTION}

\section{Interface between science and policy}

In this paper we focus on the critical interface between scientific research and government policies for sustainable catchment management. The need for increased integration between scientific communities and policy makers is well established (Funtowicz and Ravetz 1993, Lele and Norgaard 1996, Norse and Tschirley 2000, Fry 2001, Tress et al. 2005, van Kerkhoff 2005, Hirsch Hadorn et al. 2006, Toderi et al. 2007, Tress et al. 2007, Willems and de Lange 2007, Pohl 2008). Recently, there have been calls for greater integration between policies, the natural and social science evidence base, and their implementation to achieve sustainable catchment management (Macleod et al. 2007, Pahl-Wostl et al. 2007). The requirement to integrate intellectual and practical efforts of research communities and policy makers at the European Union (EU) scale in support of the Water Framework Directive (WFD) implementation has recently been discussed by Quevauviller et al. (2005). Because the WFD is implemented at the member state level, there is a growing interest in the interface between governmental departments, and the research communities upon which they rely, to direct and support their policies through the generation of an evidence base. These authors concluded that the lack of clear coordination mechanisms at EU and member state levels has led, in part, to policy research needs not being communicated to scientists and research outputs not reaching or being used by policy makers. From a UK perspective, sustainable catchment management is broader than any single EU Directive, e.g., WFD, because there is a need to also consider existing and more recent EU directives and resulting national legislation.

\section{What is integrative research?}

In Europe, there has been a drive in environmental research programs to bridge the science-policy interface through integrative research (e.g., Fry 
2001, Pohl 2005, Tress et al. 2005, Mostert et al. 2007, Tress et al. 2007). Further a field, Van Kerkhoff (2005) recently explored the broadranging concept of integration in the scientific literature and identified 12 thematic areas, including activities and institutional structures. This is an important step in allowing scientists and policy makers to understand the meaning of integration. Integrative research, as defined by Winder (2003), covers both interdisciplinary and transdisciplinary research projects. Interdisciplinary projects cross the subject boundaries of multiple academic disciplines to create new knowledge and achieve a common research goal. Transdisciplinary projects involve nonacademic participants such as policy makers, as well as academic researchers from multiple disciplines, to create new knowledge and answer a common question. There is growing recognition that greater levels of social learning between all stakeholders needs to be central to our activities if we are to improve our management of complex environmental problems, i.e., catchment management (Pahl-Wostl 2006, Ison et al. 2007, Mostert et al. 2007, Toderi et al. 2007). Integrative research seeks to pose and answer the emerging questions facing society regarding the intersection of social and natural systems, by bringing together multiple sources of knowledge, and by recognizing the new social contract for science (Lubchenco 1998).

Work by Lele and Norgaard (2005) identified four barriers to interdisciplinary work: (1) the valueladen nature of science, (2) different theories and assumptions are used by various disciplines to study the same systems, (3) differences exist in the epistemology and specific methods of different disciplines, and (4) the way in which society interacts with academia can limit how integration takes place. The authors suggest that researchers need to identify common objectives, be open to other ways of working, and allow for plurality and incompleteness. Additional barriers to integrative research include the additional time required for integration and the geographic distances between researchers (Tress et al. 2007). The challenge for integrative science is increased when the integration spans researchers and policy makers, given their different objectives. Factors impeding the sciencepolicy interaction include cultural differences, expressed in different discourses, timetables, standards for measuring excellence, and forms of accountability (de Jong 1999, Reeves et al. 2007). Therefore, integration of science and policy requires mutual understanding, communication, and the alignment of objectives.

\section{Mechanisms to aid integrative research}

This paper highlights potential mechanisms to facilitate greater integration between science and policy through demonstrating integrative research at the national scale. Science-policy interface approaches are required that acknowledge the complexity of the science and the uncertainties associated with any chosen approach, using knowledge elicitation as a technique to overcome these challenges. As such, these mechanisms are examples of the move toward deliberative policy making (Hajer and Wagenaar 2007). Mechanisms to aid integration at the science-policy interface can be classed as "opening-up" and "closing-down" (Stirling 2006), depending on whether the objective is to explore controversies and debates, or to create consensus at a particular moment given the options available.

To enable robust policy making, there is a demand for an inclusive process that enables opening up the science-policy discourse to a range of expertise, value positions, and modes of thinking (Prager and Nagel 2008). This would help to ensure that scientists and decision makers are fully informed of all the scientific and societal options, including the different perspectives underpinning these suggestions. The justification for this opening-up process is that it should provide greater transparency and accountability in decision making when confidence in environmental policy making is being questioned (Fischer 2000). An opening-up mechanism that is widely used by government departments is a consultation document, and specific questions are widely circulated to gather a selection of views from key stakeholders and interested parties before a policy decision is made. A recent example from the UK is a consultation on the protection of water against pollution from agriculture carried out by Defra (2007).

In addition to opening-up areas of the science-policy interface, there is a need for closing-down-type activities that help justify the decision-making process. To enable robust and effective policy decisions to be made, there is a need to reduce the complexity of the mass of individual research papers to a series of options that can be used by policy makers to cut through large amounts of often 
uncertain, complementary, or conflicting evidence. In the field of medicine, Goldenberg (2006) discussed the lessons that evidence-based approaches could learn from post-positive philosophy of science. The author highlighted that empirical evidence is subject to subjective interpretations and care needs to be taken not to obscure the subjective elements. An established international example of a closing-down mechanism is the work of the Intergovernmental Panel on Climate Change (IPCC), which was setup to provide decision makers and other interested parties with an authoritative source of information about climate change. Recent reports (e.g., IPCC 2007) provide a comprehensive, transparent, and balanced source of information about climate change.

Increasing awareness of the needs for, and integration of, opening-up and closing-down mechanisms for the research and policy communities could allow scientists to better align their research with key policy objectives and policy makers to influence the research required to meet these objectives. Following Stirling's (2006) analysis of the tension underlying the different rationales for each approach, it is important to realize that these opening-up and closing-down mechanisms operate at different time scales, and have different relationships between science and policy, and different requirements for engagement from the various sections of the research and policy communities. Although academics may argue that there is no single "best" solution for complex and uncertain environmental problems, and they might put more weight on "opening up" the debates, policy makers are tasked with using available knowledge to make strategic and operational policy decisions and require mechanisms to close down these debates to support policy implementation. In summary, opening up invites contestation and debate, whereas closing down seeks a temporary consensus on available solutions.

In this paper on integrative research to improve the science-policy interface at the national scale, we examine case studies of a closing-down and an opening-up mechanism, why, and how they were carried out, who was involved, what is novel about these mechanisms, how successful they were, and what we have learned from these activities. We then discuss their integration and future requirements of closing-down and opening-up mechanisms. The former is the first attempt of which we are aware to link national-scale policy instruments to an integrated assessment of the cost effectiveness of mitigation methods for agricultural diffuse pollution using an extensive and tested evidence base; the latter example is centered on an innovative coordination role that two authors of this paper provide with the Government of England and Wales (Defra) aimed at increasing integration within and between research and policy communities.

\section{CLOSING-DOWN MECHANISM: DIFFUSE POLLUTION USER MANUAL}

\section{Why is this mechanism required?}

The sustainable management of agricultural land is a key component in the success of sustainable catchment management (e.g., Sharpley et al. 1994, Withers and Lord 2002, Heathwaite et al. 2005). Over recent decades, scientists have carried out increasing numbers of research projects in an attempt to address key scientific and policy questions related to agricultural and water management. These studies, overall, have aimed at understanding single issues, e.g., fate of mineral fertilizer on the quality of surface and ground waters (e.g., Schroder et al. 2004). Government policies have mirrored the single-issue nature of the science resulting in key legislation, e.g., EU Nitrates Directive (European Union 1991). It is increasing recognized that we need to study whole systems and not just small components of systems (Holling and Meffe 1996, Holling 2001). At the same time, there is a need for broader and more integrated policies (e.g., EU WFD, Quevauviller et al. 2005). To provide national-scale management options, based on the best scientific evidence available, there is a need to integrate and synthesize many sources of evidence that are often uncertain and incomplete.

\section{How are we carrying this out and who is involved?}

To aid government policy on the management of diffuse pollution from agricultural land to inland and estuarine water bodies, two of the authors of this paper have recently contributed to a program that assessed the cost effectiveness of a wide range of diffuse pollutants, i.e., nitrogen, phosphorus, faecal indicator organisms, sediment, and mitigation methods for seven model farm systems representative of agriculture in the UK (Cuttle et al. 2007). The work was carried out by a large 
interdisciplinary team of scientists, including agronomists, biogeochemists, economists, hydrologists, modelers, and soil scientists. Each scientist has significant experience in studying the underlying pollutant behavior and in relating this to the way in which agricultural land is managed in the UK. Along side this group of scientists, key Defra science and policy staff were involved so that their needs were taken into consideration throughout the duration of the project.

A central output from this work was the Diffuse Pollution User Manual, hereafter referred to as the User Manual (Cuttle et al. 2007). To enable the effectiveness and costs to be assessed, model farm systems were set for average UK climatic conditions on clay loam and sandy loam soils. Each of the 44 selected methods (Table 1) was documented with a description, rational for adoption and means of reduction, mechanism of action, potential for applying the mechanism, practicalities of adoption, costs, effectiveness, and other benefits or risks of pollution swapping. A summary of the mitigation method "Convert arable land to extensive grassland" is provided in Appendix 1. This approach distils a large amount of scientific knowledge into a tool that can support decisions by policy makers through advising on suitable combinations of policy instruments to meet their goals. Importantly, the assumptions in farm systems, the effectiveness of the mitigation methods and their costs were included to enable a more transparent assessment of mitigation options in support of implementing river basin management plans as part of the WFD.

\section{What is the novelty and success of this mechanism?}

The novelty of this approach is the integration of a large body of scientific evidence to provide a first attempt at linking the cost effectiveness of the mitigation of a range of pollutants to actual policy instruments. Particular mitigation options can reduce the loss of a pollutant through one pathway but increase loss through another (Shepherd and Chambers 2007). However, this tool enables policy makers to assess such trade-offs and better understand the potential impacts and implications of future policies. This coproduction of a tool to link science with policy instruments is the first attempt, of which we aware, to test the cost effectiveness of a large range of mitigation methods at the national scale.
The User Manual has been adopted by leading regulatory agencies in the UK to support the implementation of policies to address diffuse pollution from agriculture. This is demonstrated by the key position of the User Manual in the recent consultation on The Protection of Water Against Pollution from Agriculture (Defra 2007). In addition, the User Manual has been used to support the implementation of the England Catchment Sensitive Farming Delivery Initiative (Defra 2006). Furthermore, the Environment Agency (England and Wales) has referred to the User Manual in its action plan, one that is targeted at farmers, which offers them guidance for making the best use of water resources (Environment Agency 2008). Internationally, similar assessments have recently been completed, others are being done across the EU, and the EU COST Action 869 is bringing them together (EU COST Action 869 2008).

\section{What lessons have we learned?}

Even though there has been a growing number of studies from around the world on the effectiveness of mitigation methods for diffuse pollution, when it came to providing robust and transparent values for their effectiveness in a variety of UK agricultural systems, this task was difficult because there was a lack of directly relevant evidence. It was recognized that the uncertainties in the baseline pollutant losses, the effectiveness of the mitigation methods, and the costs of implementing these methods needed to be examined in a more robust manner. One of the stark lessons learned by those involved was that the User Manual was being used in many situations for which it was not primarily designed, and it was being used without input from the scientists and economists that produced it. Upon completion of the User Manual, Defra immediately requested that an updated version be provided, which incorporated the cost effectiveness of a wider range of mitigation methods related to greenhouse gas emissions from agriculture. The process of producing the User Manual was devoid of input from social scientists, and this is an area that needs to be addressed in the future because the acceptability of proposed mitigation methods to farmers and other stakeholders needs to be more robustly considered. New versions of the User Manual, and other similar mechanisms need to be made available online. These should be user-friendly formats that incorporate graphics and links to supporting data so that users can better understand the basis, relevance, and potential value of the material. 
Table 1. List of the mitigation methods from the Diffuse Pollution User Manual.

\begin{tabular}{|c|c|}
\hline Category & Mitigation method \\
\hline Land use and soil management & $\begin{array}{l}\text { Convert arable land to extensive grassland } \\
\text { Establish cover crops in the autumn } \\
\text { Cultivate land for crop establishment in spring rather than autumn } \\
\text { Adopt minimal cultivation systems } \\
\text { Cultivate compacted tillage soils } \\
\text { Cultivate and drill across the slope } \\
\text { Leave autumn seedbeds rough } \\
\text { Avoid tramlines over winter } \\
\text { Establish in-field grass buffer strips } \\
\text { Loosen compacted soil layers in grassland fields } \\
\text { Maintain and enhance soil organic matter levels } \\
\text { Allow field drainage systems to deteriorate }\end{array}$ \\
\hline Livestock management & $\begin{array}{l}\text { Reduce overall stocking rates on livestock farms } \\
\text { Reduce the length of the grazing day or grazing season } \\
\text { Reduce field stocking rates when soils are wet } \\
\text { Move feed and water troughs at regular intervals } \\
\text { Reduce dietary N and P intakes } \\
\text { Adopt phase feeding of livestock }\end{array}$ \\
\hline Fertilizer management & $\begin{array}{l}\text { Use a fertilizer recommendation system } \\
\text { Integrate fertilizer and manure nutrient supply } \\
\text { Reduce fertilizer application rates } \\
\text { Do not apply P fertilizers to high P index soils } \\
\text { Do not apply fertilizer to high-risk areas } \\
\text { Avoid spreading fertilizer to fields at high-risk times }\end{array}$ \\
\hline Manure management & $\begin{array}{l}\text { Increase the capacity of farm manure (slurry) stores } \\
\text { Minimize the volume of dirty water produced } \\
\text { Adopt batch storage of slurry } \\
\text { Adopt batch storage of solid manure } \\
\text { Compost solid manure } \\
\text { Change from slurry to a solid manure handling system } \\
\text { Site solid manure heaps away from watercourses and field drains } \\
\text { Site solid manure heaps on concrete and collect the effluent } \\
\text { Do not apply manure to high-risk areas } \\
\text { Do not spread farmyard manure to fields at high-risk times } \\
\text { Do not spread slurry or poultry manure to fields at high-risk times } \\
\text { Incorporate manure into the soil } \\
\text { Transport manure to neighboring farms } \\
\text { Incinerate poultry litter }\end{array}$ \\
\hline Farm infrastructure & $\begin{array}{l}\text { Fence off rivers and streams from livestock } \\
\text { Construct bridges for livestock crossing rivers and streams } \\
\text { Re-site gateways away from high-risk areas } \\
\text { Establish new hedges } \\
\text { Establish riparian buffer strips } \\
\text { Establish and maintain artificial (constructed) wetlands }\end{array}$ \\
\hline
\end{tabular}




\section{OPENING-UP MECHANISM: INTEGRATING WATER AND AGRICULTURAL MANAGEMENT COORDINATION ROLE}

\section{Why is this mechanism required?}

Opening-up mechanisms are vital in that they allow reflection on our knowledge about a particular situation under study, what has been discovered through recent research or analysis, and how this relates to key policy objectives. Research funders increasingly recognize and demand a better understanding of the links between environmental research, which is carried out using public funds, and societal needs. Since 1984, the Framework Programme (ERFF 2008) has played a leading role in strengthening links between science and policy in Europe. Recently, the ERA-NET scheme was established to increase coordination and cooperation of research activities across the EU (CORDIS 2008). In the UK, Defra and Research Councils have recognized that links between funded environmental research and government policy is needed. In relation to the sustainable management of land and water, it is increasingly recognized that a more holistic and adaptive approach is needed with respect to the design and assessment of policies that link land and water use (e.g., Holling and Meffe 1996, Holling 2001).

Governmental policy and science staff are increasingly keen to assess the robustness, uncertainties, and gaps in the evidence base that supports water-related policy (Solesbury 2001). It is impossible to provide a static blueprint of the evidence base because of the evolving nature of science and policy, however, there is a need to pull the main information sources together in a more adaptive and discursive manner. Such online and face-to-face deliberative spaces will provide opportunities to identify, debate, and examine alternative perspectives, and these may lead to a deeper engagement with the evidence required for policy making. Because scientists are increasingly involved in transdisciplinary research projects such as the User Manual, we have suggested to Defra that there is a need to develop a more holistic approach for assessing the impact of land management on water resources.

\section{How are we carrying this out and who is involved?}

An opening-up mechanism, Integrating Water and Agricultural Management, was established in collaboration with scientists and policy makers at Defra in the UK (IWAM 2007). IWAM aims to enable greater levels of shared understanding of the science required for collaboration between relevant, but often disparate, scientific disciplines, e.g., hydrology, biogeochemistry, landscape management, economics, and sociology, and between government science and policy staff involved in assessing and managing the relationship between quality and quantity of agriculture and water resources at farm, catchment, and national scales. To enable the involvement of a large and diverse community of researchers and policy makers, there is a need to use several forms of communication and participation. We have established physical forums, e.g., national and international workshops, in which researchers and Defra staff can interact in a structured way to learn and discuss the mechanisms and science required.

The first IWAM "forming" workshop, which was held in September 2007, was attended by 19 leading researchers, 4 Defra staff, and 2 additional stakeholders. The group included scientists with expertise ranging from economics to hydrology, and policy makers covering topics from flooding to implementation of the WFD. The objective was to initiate an assessment to determine what research and analysis was required to improve our understanding of the impact of agriculture on sustainable water management under a changing climate in the UK. To achieve this, we asked breakout groups to discuss and report on the following questions: How can we improve links between research scientists and Defra science and policy staff? How can the evidence base be improved? What themes can we use to review the evidence base? A summary of the responses to the first two questions is provided in Table 2 . We used the suggestions provided by the third question to produce a matrix (Appendix 2). The matrix comprises three key areas of Defra policy, with each of these having a number of components under the broad headings of science-policy interactions, natural sciences, and socioeconomic and integrative sciences.

To increase the channels of communication and levels of learning within and between research and 
Table 2. Summary of responses from the first Integrating Water and Agricultural Management (IWAM) workshop.

How to improve the links between research scientists and policy makers?

How could the evidence base be improved?
To generate policy relevant science, policy makers need to communicate their needs to the research community. We require greater participation by policy makers for two-way exchange. Defra science and policy staff require assistance from the research community to make sure they are up to date with high quality policy relevant science. Policy relevance of a Defra final report (SID 5) needs to be included in an upfront specific section. There is a need for a greater awareness of work carried out in Scotland. Future Defra projects must have the policy implications stated clearly, so that the researcher is aware of what the policy maker may need and how they plan to use the outputs. Adoption of a "Milk round" type approach to get across key facts to policy makers. Interface with Defra Science Advisory Council. Science-policy translators/intermediaries have an important role.
We have made progress in understanding the drivers, states, and impacts of environmental policy issues. Defra science and policy staff need to carefully define what evidence is required. Greater integration with relevant research in Defra and external research is required e.g. RELU and Living with Environmental Change (LWEC). Research outputs should be framed in terms of activities that end users will need to do to improve the quality of the environment. There is a need to improve the scientific basis of current policy instruments e.g., environmental stewardship based on the best available science. There is a need to relate what scientists see as gaps and uncertainties to current and future policy needs. How to rank gaps in different subject areas?

Feedback on WQ0109 Defra coordination activities are a welcome activity. There is a need for more integrated activities Integrating Agricultural as well as more detailed subject specific assessment of the gaps and uncertainties in key policy and Water Management science areas. Science theme leaders need to have a policy contact, so what they do is policy relevant. Greater involvement of ecologists, social scientists and water resource hydrologists is essential.

policy communities over a broad and disparate range of natural and social science disciplines, we used the concept of science leaders who form thematic hubs to explore and report on the gaps and uncertainties of the science-policy evidence base. Following our first workshop, we advertised in search of science theme leaders who could provide a focal point for assessing defined areas as identified in the science-policy matrix. Scientists were asked to nominate themselves based on clear assessment criteria, roles, and responsibilities. A small honorarium was offered to help encourage involvement. Based on the 14 applications received, three science-policy themes/groups were formed. These were: climate change, land use and runoff, integrated governance across multiple scales, and farm-to-catchment-scale risks from organic materials. Each theme comprised three scientists and at least two Defra policy and science contacts. The initial task of each group was to produce an overview of the key issues that would later be reviewed at an International Workshop on Agriculture, Water Management, and Climate Change. More than 60 delegates, from several countries, attended the workshop (International Workshop on Agriculture, Water Management, and Climate Change 2008).

In addition to these workshops, we established virtual forums via a Web portal, and wrote an associated blog in which interested parties could keep up-to-date and participate without having to leave their offices or homes. For example, the slide and video presentations from our first workshop were made available online along with the summaries from breakout and plenary sessions. There is growing use of Web portals that serve as interfaces between scientists and stakeholders (e.g., Willems and de Lange 2007). This is, in part, a result of the recent increases in broadband Internet availability access across Europe, reducing the "digital divide" and improving access, but also 
because of the demands from a wide range of stakeholders, including researchers and policy makers, for instant access to scientific and policy guidance about important issues. The potential advantage of the blog approach is that it allows a wide range of scientists to post concise information on topics, and it enables interested readers to respond or to find more information as required. These physical and virtual forums support one another. We have also produced an electronic newsletter to update scientists and policy makers on recent developments.

\section{What is the novelty and success of this mechanism?}

We believe that this opening-up mechanism is novel in four ways. First, the emphasis is on exploring both the breadth and the depth of the evidence base to better link research and policy, and to increase our understanding of all aspects of sustainable agricultural and water management. The use of physical and virtual forums sustained through time to allow ongoing and adaptive exchange of ideas and learning has enabled a larger proportion of the science and policy communities to participate than would have been possible through physical activities alone. The use of Web analytics has enabled us to understand how and when science and policy communities participate virtually. And, finally, the use of science theme leaders provides a more holistic assessment of the requirements for sustainable catchment management by drawing upon a network of interested researchers and policy makers. We believe that this study presents a first example of integrative national-scale activity for sustainable catchment management.

The IWAM Web portal (IWAM 2007) was established in July 2007, and in the first year of operation it received numerous visits, bearing in mind the specialized content of the site (Table 3 ). During the first year, the Web portal received the majority of its hits from $83 \%$ of page views, with the associated blog receiving a lower proportion (17\%). Of the 8745 page views by 1774 individuals, pages introducing the IWAM mechanism received the greatest number of views $(29 \%)$, followed by those related to the first IWAM "forming" and following international workshops $(22 \%)$, with a smaller number of views $(6 \%)$ on pages related to the science theme leaders. In this first year there were 64 posts from the lead scientists, with five of these posts viewed over 50 times. The most popular posts were those related to recent scientific papers and reports, forthcoming conferences, and employment opportunities. We did not stimulate significant comment and debate using the blog. However, we did ask the participants of workshops and the recipients of newsletters to participate on numerous occasions. This may have resulted from the nature of the posts, the way in which we set up and communicated IWAM, or the lack of participation may have been due to the preference of the scientists, e.g., they may have wanted to have more focused forms of communication such as peerreviewed papers or conferences.

We were able to record the usage of the IWAM Web portal using Web analytics. This is especially useful when demonstrating IWAM's success to the funding parties. Web analytics has also enabled us to learn of those interested in our work, and specifically, how well-received particular items have been. For example, there was an increase in the level of activity following our first "forming" workshop. Table 3 shows that following the initial workshop, the number of new people visiting the Web portal increased by $247 \%$, and the number of page views increased by $170 \%$.

\section{What lessons have we learned?}

During our first "forming" workshop, we requested feedback on how to improve the IWAM coordination role (Table 2). The greatest challenge has been the breadth of IWAM and trying to engage with a broad range of disciplines and policy areas. When we began, we wanted to take a holistic view of the science-policy interactions associated with agriculture and water management. This was too broad an area, and no one person could provide the required level of integration and analysis. The deployment of science theme leaders was successful in that a larger proportion of the science-policy interface could be included, and at the same time, we were able to retain scientific and policy credibility. The three thematic areas were not designed to cover the entirety of the potential evidence base, and it is important that future thematic activities cover missing areas.

In the first workshop, valuable suggestions on how the links between the research and policy, as well as how the evidence base could be improved (Table 2 ) were provided. A key finding was that there is a 
Table 3. Web analytics from the first year of the Integrating Water and Agricultural Management (IWAM) Web portal.

Time period

\begin{tabular}{|c|c|c|c|}
\hline Dates & 190707 to 180907 & 190907 to 181107 & 190707 to 180708 \\
\hline Period & $\begin{array}{l}\text { First two months prior to } \\
\text { forming workshop }\end{array}$ & $\begin{array}{l}\text { Two months following } \\
\text { forming workshop }\end{array}$ & First year \\
\hline Page views & 1681 & 2854 & 8745 \\
\hline People & 184 & 454 & 1774 \\
\hline Visits & 461 & 753 & 2994 \\
\hline Average page views & 3.65 & 3.79 & 2.92 \\
\hline Time on site & $3 \mathrm{~m} 28 \mathrm{~s}$ & $2 \mathrm{~m} 58 \mathrm{~s}$ & $2 \mathrm{~m} 11 \mathrm{~s}$ \\
\hline
\end{tabular}

great need for two-way science-policy interactions. To align research interests and time scales to those of policy makers is challenging. However, there are a number of initiatives aimed at improving this at the EU level, e.g., ERA-NET scheme (CORDIS 2008) and the Environmental Research Funders' Forum (ERFF 2008) are important examples of efforts that work to increase the effectiveness and coherence of environmental research. It is important that the objectives, boundaries, and definitions associated with IWAM are clear. As highlighted in the introduction, there are many challenges to integrative research (Lele and Norgaard 2005). The different epistemology and associated methods of quantitative and qualitative scientific disciplines have on occasion meant that more time is required to improve communication.

Information alone does not equate to improving knowledge or stimulating learning. First, the provision of technical information can shut down debate (e.g., Steyaert and Ollivier 2007), unless it is done in a context that encourages discussion. Providing physical and online forums, e.g., Web portals, rather than a Web site is crucial, because portals encourage comments and debate. They also allow actors within the science-policy community to highlight information that proved useful, and could be of benefit to others. More practically, for any blog or workshop to be useful, it needs to be accessible to its intended audience. Literature on the use of information and on communications technology (ICT) for public engagement suggests that ICT can be a useful engagement tool, providing that the audience desires the content and is aware of its existence (e.g., Quinn and Ramasurbramanian 2007). Furthermore, decision-support tools for evaluation in agriculture indicate that unless the content is seen to be salient, credible, and relevant, the transaction and opportunity costs of accessing and using such technologies prevent their uptake and use (Matthews et al. 2008). An important component of IWAM is the reporting from the themes to the wider community through physical workshops and the Web portal to enable feedback at various stages through the coordination role.

\section{LINKAGES BETWEEN OPENING-UP AND CLOSING-DOWN MECHANISMS}

We believe that there is an urgent need to create stronger and more transparent, integrated, and adaptive linkages between opening-up and closingdown mechanisms at the science-policy interface. Policy makers need to involve the research community throughout the policy cycle and over several science-policy review cycles to improve the setting of future research priorities (Pohl 2008). As Stirling (2006) shows, policy makers require 
justification for decisions; hence, closing-down mechanisms, but also benefit from opening up the debate as this can increase the legitimacy of decisions made at a later date. Therefore openingup and closing-down processes are linked in an ongoing adaptive cycle as shown in Fig. 1, because improving understanding and communication between policy makers and researchers is more likely to improve the ability to use research more effectively to inform policy. These decisions need to be based on an assessment of our status in relation to the uncertainties and gaps in the evidence base supporting key policy objectives. These uncertainties remind both scientists and policy makers that all decisions are partial and contingent; therefore, any closed-down decision will be opened up again in the future. This coevolution of research and policy is particularly important when dealing with complex problems such as climate change.

The ongoing cyclical nature can be demonstrated by the fact that in the case studies presented, the closing-down activity was carried out before the establishment of the opening-up mechanism. Reflection on the part of the team of scientists and policy makers identified that the first attempt at writing the User Manual could have been improved, for example, by having a greater recognition of the uncertainties in the information presented. This stimulated the need to reopen the debate, and as part of the opening-up mechanism, one of the science themes will revisit the work carried out under the closing-down activity and will review how this can be updated in light of developments in the science and policy with which it links. As Appendix 1 demonstrates, the user manual project was undertaken in a systematic manner, which provides scientific rigor but possibly at the expense of systemic thinking. Opening-up mechanisms use an alternative epistemological perspective that highlights holistic and creative thinking, but increases complexity and uncertainty, questioning the decisions made in the manual. Furthermore, linking the two mechanisms together also raises questions about implementation of policy, and these are further challenges to be tackled in partnership between scientists, policy makers, and society. However, this is not tackled within the scope of this paper.

\section{FUTURE REQUIREMENTS FOR INTEGRATION AT THE SCIENCE-POLICY INTERFACE}

Our reflections on the case studies highlight that, although far from perfect, they have provided a step toward integration. The remaining section focuses on how these lessons could be taken forward. Improving links between research scientists and government science and policy staff is increasing required because of the complexity the underlying science and the evolving and complicated nature of environmental policies. Recently, there have been advances in the integration of social and natural sciences that provide a more holistic understanding of how sustainable land and water management are related from the field to catchment scales, e.g., EU projects SLIM and NeWater (Pahl-Wostl 2006, Ison et al. 2007, Mostert et al. 2007). Many of these projects use participatory and deliberative methods to open up and debate the nature of diffuse pollution problems and solutions. As these scientific studies gather in number and increase our understanding of the requirements for sustainable catchment management, there will be a need for more advanced closing-down mechanisms that can distil this new knowledge to support policy decisions.

We are only starting to tackle the challenges faced when trying to establish greater awareness, transparency, and integration at the science-policy interface, yet this is essential if we are to create a more appropriate evidence base to support our management of terrestrial and aquatic resources from the farm to the national scale. A key issue is the need to improve lines of communication and understanding between research scientists and governmental staff. Technology has an important role to play in improving the interface between science and policy. Metadatabases enable scientists and policy makers to access information on science and policy projects and, with reference to networking, identify collaborators of interest. One example of aiding communication is the use of Internet-based science-policy interfacing instruments that use keywords to map user requirements to the available information (Willems and de Lange 2007). The potential of Internet-based virtual laboratories for social and natural scientists has been reviewed recently by Bainbridge (2007). We have found that it is important that such virtual tools and networks be supported by physical activities to encourage and maintain strong collaborations between scientists and policy makers. The use of 
Fig. 1. Integration between closing-down and opening-up activities.

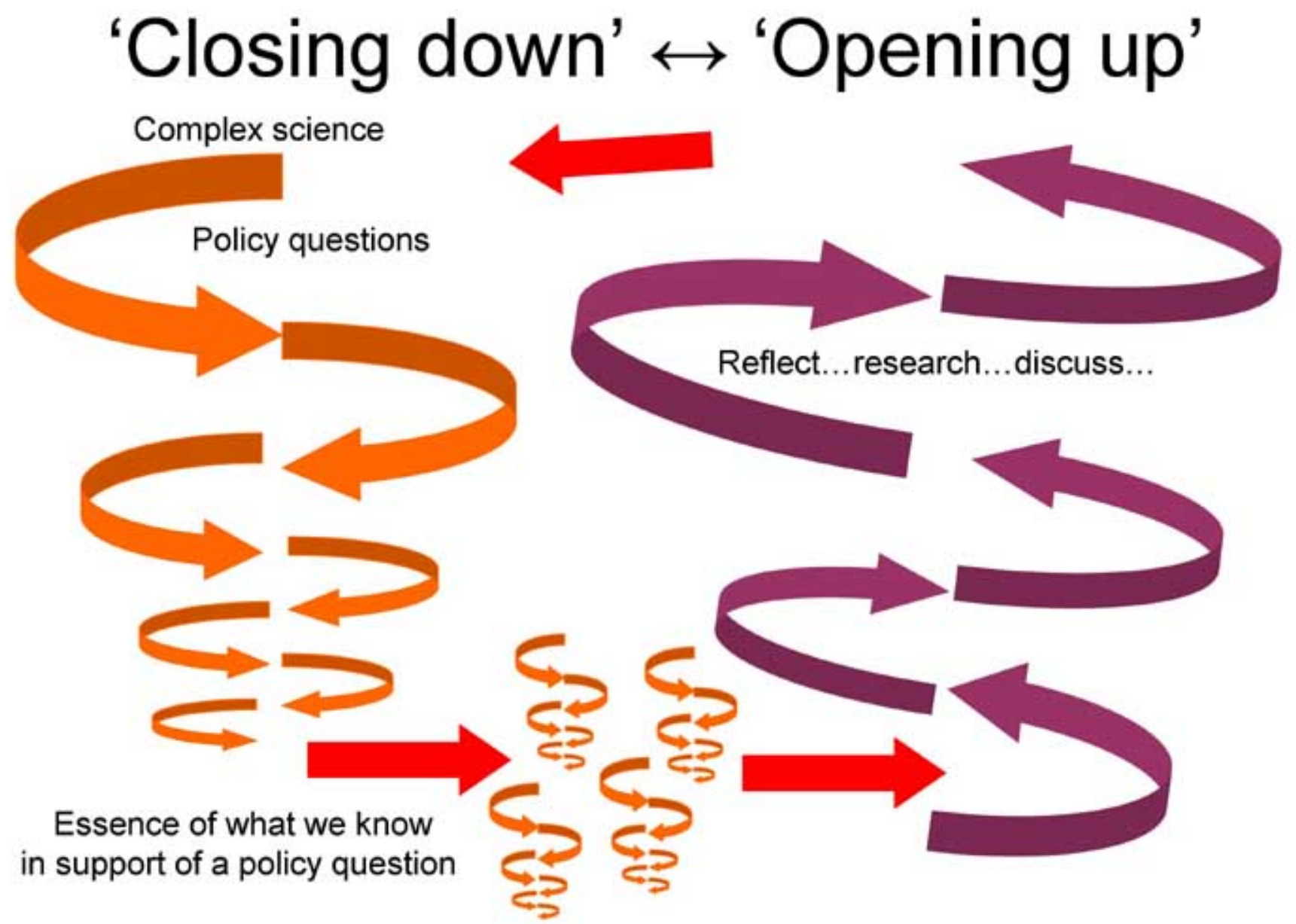

Web analytics in the field of environmental sciences has the potential to benefit numerous integrative research projects.

Equally, increasing social capital, including establishing shared norms, sense of reciprocity, and trust, will enable greater awareness, ownership, and integration (Mostert et al. 2007). In the UK, there have been an increasing number of initiatives aimed at increasing the levels of social capital. These include the Rural Economy and Land Use (Relu 2008) and the newly established Living With Environmental Change Integrative Research programs (NERC 2008). To aid in communication, it is important that improved mechanisms, which help establish and maintain working relationships across the science-policy interface, are developed to take into consideration the regular movement of staff within the civil service.

\section{How will these changes influence how researchers operate?}

There is growing recognition in a wide range of scientific disciplines that more interdisciplinary and transdisciplinary research is needed to tackle the major environmental challenges of the 21 st century 
(Funtowicz and Ravetz 1993, Norse and Tschirley 2000, Tress et al. 2005, 2007; Hirsch Hadorn et al. 2006, Macleod et al. 2007, Toderi et al. 2007). In addition, funders of research are making it clear that greater integration is required in research proposals if science is to help answer these cross-cutting questions about environmental management. To ensure that research is directed at the right questions, it is essential that we move toward coproduction of knowledge; this comes from the direction of research that has policy makers and potential users involved in a two-way dialogue from conception (Letcher and Giupponi 2005).

We believe that there will be changes with respect to how individual research projects are carried out, and also to the way in which scientific meetings are organized and conducted. With the growth in the number of integrative scientific meetings, there is a need to recognize the potential barriers to achieving integrative research (Lele and Norgaard 2005, Tress et al. 2007). This should result in greater care in the planning of integrative activities and consideration of social/collaborative learning as a key component of these activities (Pahl-Wostl 2006, Ison et al. 2007, Mostert et al. 2007, Toderi et al. 2007). Recognizing whether the objective of a meeting at the interface is to open up debate or close down debates, to help implement decisions, is an important component of such processes as our study has shown.

\section{CONCLUSIONS}

This paper has highlighted the need for improved science-policy interfaces and how this might be delivered through integrative research. We have provided two examples of UK-based integrative research activities at the national scale for sustainable catchment management. As well as describing why such approaches are needed, we discuss their interaction and future requirements for such interface activities. The examples highlight the need to have a balance between opening-up and closing-down activities and the recognition that these activities are linked through ongoing policyresearch cycles. Thus, our conclusions, based on our UK case studies resonate with an international discussion on the need for integrated science that coevolves with policy. We propose that if more scientists take on coordination roles such as we did, greater awareness, transparency, understanding, and integration between research and policy communities can be established and maintained.
Responses to this article can be read online at: http://www.ecologyandsociety.org/voll3/iss2/art48/responses/

\section{Acknowledgments:}

The WQ0109 Water coordination role and ES0203 Diffuse Pollution User Manual were funded by Defra, UK. North Wyke Research is a BBSRC, UKfunded Research Institute. The paper also draws on concepts developed under Scottish Governmentfunded research RO105353: Managing at a catchment scale.

\section{LITERATURE CITED}

Bainbridge, W. S. 2007. The scientific research potential of virtual worlds. Science 317:472-476.

Coordination of Research Activities (CORDIS). 2008. ERA-NET scheme. Available online at: http:/ lcordis.europa.eu/coordination/er-net.htm.

Cuttle, S. P., C. J. A. Macleod, D. R. Chadwick, D. Scholefield, P. M. Haygarth, P. Newell-Price, D. Harris, M. A. Shepherd, B. J. Chambers, and R. Humphrey. 2007. An inventory of methods to control diffuse water pollution from agriculture (DWPA): user manual. Defra, London, UK.

de Jong, M. 1999. Institutionalised criticism: the demonpolisation of scientific advising. Science and Public Policy 23:193-199.

Department for Environment, Food, and Rural Affairs (Defra). 2006. The England catchment sensitive farming delivery initiative (ECSFDI). Available online at: http://www.defra.gov.uk/FARM/ environment/water/csf/delivery-initiative.htm.

Department for Environment, Food, and Rural Affairs (Defra). 2007. The protection of waters against pollution from agriculture. Defra, London, UK.

Department for Environment, Food, and Rural Affairs (Defra). 2008. International Workshop on Agriculture, Water Management, and Climate Change (Bath, UK, 2008). Defra, Bath, UK.

Environment Agency. 2007. WaterWise on the farm. Version 2. A simple guide to implementing a 
water management plan. Environment Agency, Bristol, UK.

Environmental Research Funders' Forum (ERFF). 2008. UK-Environmental Observation Framework (ERFF Report 05) presents the concept, aims, proposed outcomes, structure, and benefits of the new UK-Environmental Observation Framework (UK-EOF). Available online at: http://www.erff.org. $\underline{\mathrm{uk}}$.

EU COST Action 869. 2008. EU COST Action 869: mitigation options for nutrient reduction in surface water and groundwaters. Available online at: http: //www.cost869.alterra.nl/.

European Union. 1991. Implementation of Nitrates Directive. Available online at: http://ec.europa.eu/e nvironment/water/water-nitrates/index en.html.

Fischer, F. 2000. Citizens, experts, and the environment: the politics of local knowledge. Duke University Press, London, UK.

Fry, G. L. A. 2001. Multifunctional landscapestowards transdisciplinary research. Landscape and Urban Planning 57:159-168.

Funtowicz, S. O., and J. R. Ravetz. 1993. Science for the post-normal age. Futures 25:739-755.

Goldenberg, M. J. 2006. On evidence and evidence-based medicine: lessons from the philosophy of science. Social Science and Medicine 62:2621-2632.

Hajer, M. A., and H. Wagenaar. 2007. Deliberative policy analysis: understanding governance in network society. Cambridge University Press, Cambridge, UK.

Heathwaite, A. L., P. F. Quinn, and C. J. M. Hewett. 2005. Modelling and managing critical source areas of diffuse pollution from agricultural land using flow connectivity simulation. Journal of Hydrology 304:446-461.

Hirsch Hadorn, G. H., D. Bradley, C. Pohl, S. Rist, and U. Wiesmann. 2006. Implications of transdisciplinarity for sustainability research. Ecological Economics 60:119-128.
Holling, C. S. 2001. Understanding the complexity of economic, ecological, and social systems. Ecosystems 4:390-405.

Holling, C. S., and G. K. Meffe. 1996. Command and control and the pathology of natural resource management. Conservation Biology 10:328-337.

Intergovernmental Panel on Climate Change (IPCC). 2007. Climate change 2007: impacts, adaptation, and vulnerability. Contribution of Working Group II to the Fourth Assessment Report of the Intergovernmental Panel on Climate Change. IPCC, Cambridge University Press, Cambridge, UK.

Ison, R., N. Roling, and D. Watson. 2007. Challenges to science and society in the sustainable management and use of water: investigating the role of social learning. Environmental Science and Policy 10:499-511.

Integrating Water and Agricultural Management (IWAM). 2007. Integrating water and agricultural management. Available online at: http://www.north wyke.bbsrc.ac.uk/IWAMwebsite/Index.htm.

Lele, S., and R. B. Norgaard. 1996. Sustainability and the scientist's burden. Conservation Biology 10:354-365.

Lele, S., and R. B. Norgaard. 2005. Practicing interdisciplinarity. Bioscience 55:967-975.

Letcher, R. A., and C. Giupponi. 2005. Policies and tools for sustainable water management in the European Union. Environmental Modelling and Software 20:93-98.

Lubchenco, J. 1998. Entering the century of the environment: a new social contract for science. Science 279:491-497.

Macleod, C. J. A., D. Scholefield, and P. M. Haygarth. 2007. Integration for sustainable catchment management. Science of The Total Environment 373:591-602.

Matthews, K. B., G. Schwarz, K. Buchan, M. Rivington, and D. Miller. 2008. Wither agricultural DSS? Computers and Electronics in Agriculture 61:149-159. 
Mostert, E., C. Pahl-Wostl, Y. Rees, B. Searle, D. Tabara, and J. Tippett. 2007. Social learning in European river-basin management: barriers and fostering mechanisms from 10 river basins. Ecology and Society 12(1):19. [online] URL: http://www.ec ologyandsociety.org/vol12/iss1/art19/.

Natural Environment Research Council (NERC). 2008. Living with environmental change. Available online at: http://www.nerc.ac.uk/research/programmes/ lwec/.

Norse, D., and J. B. Tschirley. 2000. Links between science and policymaking. Agriculture, Ecosystems and Environment 82:15-26.

Pahl-Wostl, C. 2006. The importance of social learning in restoring the multifunctionality of rivers and floodplains. Ecology and Society 11(1):10. [online] URL: http://www.ecologyandsociety.org/voll1/ iss1/art10/.

Pahl-Wostl, C., J. Sendzimir, P. Jeffrey, J. Aerts, G. Berkamp, and K. Cross. 2007. Managing change toward adaptive water management through social learning. Ecology and Society 12(2):30. [online] URL: http://www.ecologyandsociety.org/vol12/ iss $2 / \operatorname{art} 30 /$.

Pohl, C. 2005. Transdisciplinary collaboration in environmental research. Futures 37:1159-1178.

Pohl, C. 2008. From science to policy through transdisciplinary research. Environmental Science and Policy 11:46-53.

Prager, K., and U. J. Nagel. 2008. Participatory decision making on agri-environmental programmes: a case study from Sachsen-Anhalt (Germany). Land Use Policy 25:106-115.

Quevauviller, P., P. Balabanis, C. Fragakis, M. Weydert, M. Oliver, A. Kaschl, G. Arnold, A. Kroll, L. Galbiati, J. M. Zaldivar, and G. Bidoglio. 2005. Science-policy integration needs in support of the implementation of the EU Water Framework Directive. Environmental Science and Policy 8:203-211.

Quinn, A. C., and L. Ramasurbramanian. 2007. Information technologies and civic engagement: perspectives from librarianship and planning. Government Information Quarterly 24:595-610.
Reeves, A. D., E. A. Kirk, and K. L. Blackstock. 2007. The limitations of regulatory science in the effective control of diffuse pollution. Law, Science and Policy 3:123-156.

Rural Economy and Land Use Programme (RELU). 2008. Harnessing the social and natural sciences for sustainable rural development. Available online at: http://www.relu.ac.uk/.

Schroder, J. J., D. Scholefield, F. Cabral, and G. Hofman. 2004. The effects of nutrient losses from agriculture on ground and surface water quality: the position of science in developing indicators for regulation. Environmental Science and Policy 7:15-23.

Sharpley, A. N., S. C. Chapra, R. Wedepohl, J. T. Sims, T. C. Daniel, and K. R. Reddy. 1994. Managing agricultural phosphorus for protection of surface waters: Issues and options. Journal of Environmental Quality 23:437-451.

Shepherd, M., and B. Chambers. 2007. Managing nitrogen on the farm: the devil is in the detail. Journal of the Science of Food and Agriculture 87:558-568.

Solesbury, W. 2001. Evidence based policy: whence it came and where it's going. Economic and Social Research Council Centre for EvidenceBased Policy and Practice, London, UK.

Steyaert, P., and G. Ollivier. 2007. The European Water Framework Directive: how ecological assumptions frame technical and social change. Ecology and Society 12(1):25. [online] URL: http:/ /www.ecologyandsociety.org/vol12/iss 1/art25/.

Stirling, A. 2006. Analysis, participation and power: justification and closure in participatory multi-criteria analysis. Land Use Policy 23:95-107.

Toderi, M., N. Powell, G. Seddaiu, P. P. Roggero, and D. Gibbon. 2007. Combining social learning with agro-ecological research practice for more effective management of nitrate pollution. Environmental Science and Policy 10:551-563.

Tress, B., G. Tress, and G. Fry. 2005. Integrative studies on rural landscapes: policy expectations and research practices. Landscape and Urban Planning 70:177-191. 
Tress, G., B. Tress, and G. Fry. 2007. Analysis of the barriers to integration in landscape research projects. Land Use Policy 24:374-385.

van Kerkhoff, L. 2005. Integrated research: concepts of connection in environmental science and policy. Environmental Science and Policy 8:452-463.

Willems, P., and W. J. de Lange. 2007. Concept of technical support to science-policy interfacing with respect to the implementation of the European Water Framework Directive. Environmental Science and Policy 10:464-473.

Winder, N. 2003. Successes and problems when conducting interdisciplinary or transdisciplinary (= integrative) research. Pages 74-90 in B. Tress, G. Tress, and G. Fry, editors. Potential limitations of interdisciplinary and transdisciplinary landscape studies. Delta Series 2. Alterra Green World Research and Wageningen University, Wageningen, The Netherlands.

Withers, P.J.A., and E. I.Lord. 2002. Agricultural nutrient inputs to rivers and groundwaters in the UK: policy, environmental management and research needs. Science of the Total Environment 282:9-24. 
Appendix 1. Summary of a mitigation method from the User Manual

Please click here to download file 'appendix1.pdf'. 
Appendix 2. Matrix of science-policy evidence base from the first IWAM workshop

Please click here to download file 'appendix2.pdf'. 